\title{
Self-Instruction Training untuk Meningkatkan Resiliensi Siswa Sekolah Menengah Atas
}

\author{
Anggi Azzi Purnama \\ SMA Negeri 1 Mangunjaya, Pangandaran \\ anggiazzipurnama@gmail.com
}

\begin{abstract}
Abstrak
Resiliensi merupakan faktor esensial dalam perkembangan hidup remaja. rendahnya resiliensi pada remaja menjadikan remaja yang rentan (vulnerable adolescence) dan remaja yang rentan memiliki kecenderungan yang tinggi untuk menjadi remaja yang bermasalah. Tujuan akhir penelitian ini menghasilkan program pelatihan selfinstruction training untuk meningkatkan resiliensi siswa. Untuk mencapai tujuan tersebut digunakan metode penelitian quasi experimen dengan desain non-equivalent pretest-posttest control group. Dalam pelaksanaanya, penelitian ini melalui tiga langkah utama, yakni (1) langkah pertama adalah mengungkap kondisi awal/ profil umum resiliensi siswa; (2) langkah kedua, perumusan program pelatihan self-instruction untuk meningkatkan resiliensi siswa; dan (3) langkah ketiga pengujian efektivitas penerapan program pelatihan self-instruction untuk meningkatkan resiliensi siswa. Penelitian menemukan bahwa mayoritas siswa berada pada kategori cukup resilien dengan tingkat kecenderungan resiliensi yang dominan ditunjukkan oleh remaja adalah tingkatan sedang, atau rata-rata (average), atau moderat. Setelah pelaksanaan intervensi, resiliensi siswa meningkat terutama pada aspek efikasi diri, penilaian realistis terhadap lingkungan, problem solving, dan planning \& goal setting. Hal ini menandakan program pelatihan self-instruction secara empirik efektif dalam meningkatkan resiliensi siswa.
\end{abstract}

Kata Kunci: Self-Instruction Training; Resiliensi Siswa; Remaja.

\section{PENDAHULUAN}

Remaja dengan segala keunikannya sangat rentan menghadapi berbagai masalah yang menghambat perkembangan dirinya baik itu dari faktor dalam dirinya ataupun dari lingkungannya, sehingga ketika masalah tersebut tidak teratasi maka akan berdampak pada tersendatnya perkembangan pada tahap perkembangannya (Hurlock, 2003; Santrock, 1996 Slavin, 2011). Salah satu faktor penyebab munculnya masalah dalam perkembangan remaja adalah pengalaman terhadap adversitas, yaitu berbagai masalah atau peristiwa kemalangan yang dialami remaja. Adversitas dapat berupa musibah, pengalaman buruk, peristiwa negatif, kejadian tidak menyenangkan, kondisi sarat resiko, situasi stres yang berat, serta kondisi yang menyebabkan traumatis (Linley \& Josep, 2004, hlm. 5). 
Pengalaman terhadap adversitas dapat memicu konflik dalam diri remaja yang membuat mereka rentan terhadap berbagai perilaku maladaptif. Pernyataan ini diperkuat oleh Schoon (2006, hlm. 5) mengemukakan bahwa adversitas dapat membawa pada resiko, remaja beresiko (at-risk adolesence) biasanya menjadi remaja yang rentan (vulnerable adolesence) dan remaja yang rentan memiliki kecenderungan yang tinggi untuk menjadi remaja bermasalah (troubled adolesence). Sedangkan remaja bermasalah menurut Slavin (2011, hlm. 117) menghasilkan gangguan emosi, bullying, putus sekolah, penggunaan NAFZA, kenakalan, resiko kehamilan, penyakit menular, dan identitas seksual.

Lebih jauh Drykoos (1998; dalam Slavin, 2011) menjelaskan masa remaja dapat menjadi saat yang beresiko besar bagi banyak orang, karena remaja untuk pertama kalinya terlibat ke dalam perilaku atau pengambilan keputusan yang mempunyai konsekuensi negatif jangka panjang ketika dihadapkan pada suatu masalah. Selain berakibat pada kecenderungan terjadinya masalah remaja berupa kenakalan, pengalaman terhadap adversitas juga dapat mempengaruhi kondisi mental seseorang. Orang yang baru mengalami adversitas biasanya akan menjadi rapuh dan sangat beresiko terhadap berbagai masalah patologis seperti frustasi, depresi, paranoid, kesedihan berkepanjangan, histeria, stress berat, schizofrenia, dan akibat fatal lainnya seperti bunuh diri (Morland, 1999, hlm. 40).

Berkenaan dengan adversitas, beberapa remaja gagal karena tidak berhasil keluar dari situasi yang tidak menguntungkan, namun ada pula remaja yang mampu bertahan dan pulih dari adversitas yang pernah dialaminya. Kemampuan untuk melanjutkan hidup setelah ditimpa kemalangan atau bertahan ditengah lingkungan dengan tekanan yang berat bukanlah sebuah keberuntungan, hal tersebut menunjukkan adanya kemampuan tertentu dalam diri individu yang dikenal dengan istilah resiliensi (Tugade \& Frederikson, 2004, hlm. 4). Resiliensi dipandang sebagai kemampuan untuk bangkit kembali dari situasi atau peristiwa yang traumatis.

Joseph (dalam Isaacson, 2002) menyatakan bahwa resiliensi adalah kemampuan individu untuk menyesuaikan diri dan beradaptasi terhadap perubahan, tuntutan, dan kekecewaan yang muncul dalam kehidupan. Hal senada diungkapkan Liquanti (1992, hlm. 2) yang menyebutkan secara khusus bahwa resiliensi merupakan kemampuan yang dimiliki seseorang dimana mereka tidak mengalah saat menghadapi tekanan dan perubahan dalam lingkungan. Mereka juga senantiasa terhindar dari penggunaan obat terlarang, kenakalan remaja, kegagalan akademik, depresi, stres berkepanjangan, perilaku menyimpang dan gangguan mental.

Beberapa hasil penelitian mendukung bahwa rendahnya tingkat resiliensi dalam diri individu akan menimbulkan kerentanan terhadap resiko dari adversitas. Masten (1994; dalam Davis, 2009, hlm. 1) melakukan penelitian longitudinal dan cross sectional. Topik yang diteliti adalah tingkat resiliensi anak dikaitkan dengan berbagai permasalahan keluarga disfungsi seperti orangtua dengan gangguan jiwa, kesulitan finansial, ibu remaja, penyakit kronis, kriminalitas, penelantaran dan penganiayaan. Setelah 20 tahun masa penelitian diperoleh hasil yang mengindikasikan bahwa anak yang tumbuh dalam keluarga disfungsi, atau yang mengalami penelantaran dan penganiayaan cenderung memiliki resiliensi diri 
yang rendah dan tumbuh menjadi orang dewasa yang rentan, dikarenakan dalam perkembangannya lebih banyak peristiwa yang memicu stress dan kurang mampu mengatasi tekanan yang ditimbulkan oleh peristiwa tersebut.

Morland (1996; dalam Barnard, 1999, hlm. 40), mengemukakan bahwa terdapat kecenderungan faktor-faktor resiliensi yang rendah dalam diri anak atau remaja terutama yang berasal dari kelompok sosioekonomi rendah dan yang telah mengalami dukacita kehilangan orangtua. Irawati (2008; dalam Anesty, 2012) melakukan penelitian terhadap resiliensi remaja dari keluarga brokenhome. Hasil penelitian mengungkap bahwa hanya $17 \%$ dari remaja brokenhome yang mampu membekali diri dengan kemampuan resiliensi dalam menghadapi berbagai persoalan yang datang setelah perceraian orangtua, sebanyak $58 \%$ cenderung mengalami masalah kepribadian dan 26\% terlibat dalam aksi kenakalan remaja.

Asumsi mendasar dalam studi mengenai resiliensi ini adalah bahwa beberapa individu tetap baik-baik saja meskipun telah mengalami situasi yang sarat adversitas dan beresiko, sementara beberapa individu lainnya gagal beradaptasi dan terperosok dalam adversitas atau resiko yang lebih berat lagi (Schoon, 2006, hlm. 9). Resiliensi merupakan faktor esensial dalam perkembangan hidup remaja. Rendahnya resiliensi pada remaja perlu diberikan perhatian oleh berbagai kalangan, karena menurut Schoon (2006, hlm. 5) rendahnya resiliensi pada remaja menjadikan remaja yang rentan (vulnerable adolescence) dan remaja yang rentan memiliki kecenderungan yang tinggi untuk menjadi remaja yang bermasalah (troubled adolescence).

Sedangkan resiliensi tinggi akan mampu mengelola permasalahan menjadi kekuatan dan keterampilan untuk bertahan dalam lingkungan sarat tekanan dan untuk bangkit kembali menuju keberfungsian normal (Hetherington dan Blechman, dalam Isaacson, 2002). Oleh karena itu, resiliensi dianggap sebagai kekuatan dasar yang menjadi fondasi dari semua karakter positif dalam membangun kekuatan emosional dan psikologis remaja. Tanpa adanya resiliensi, tidak akan ada keberanian, ketekunan, dan rasionalitas. Bahkan resiliensi diakui sangat menentukan gaya berpikir dan keberhasilan siswa dalam kehidupan, termasuk keberhasilan dalam belajar di sekolah (Desmita, 2009, hlm. 199).

Sejumlah fakta empiris mengenai pengalaman adversitas dan kaitannya dengan kecenderungan terhadap berbagai gangguan perilaku semakin menambah penekanan pentingnya resiliensi dalam diri remaja. Hal ini mengisyaratkan perlunya upaya meningkatkan resiliensi remaja, agar remaja memiliki kemampuan untuk bangkit dan meningkatkan kapasitas resiliensi khususnya remaja dengan pengalaman terhadap adversitas dan beresiko tinggi terhadap gangguan perilaku dan kegagalan di semua aspek kehidupannya termasuk kegagalan pendidikan. Peneliti memandang perlu adanya upaya peningkatan resiliensi dengan menerapkan keterampilan tertentu bagi individu yang lebih praktis dan dapat dilakukan sendiri oleh semua individu sehingga ketika dihadapkan dengan adversitas dan menurunnya resiliensi, individu tersebut dengan mandiri mampu meningkatkan resiliensinya.

Teknik yang digunakan peneliti untuk meningkatkan resiliensi adalah teknik selfinstruction training yang merupakan salah satu teknik dalam terapi kognitif-perilaku. 
Meichenbaum \& Goodman (1971) pada awalnya mengembangkan pelatihan selfinstructional untuk membantu anak mengontrol perilaku impulsif. Meichenbaum (1986) kemudian menggunakan strategi pelatihan self-instructional untuk membantu klien mengembangkan keterampilan coping dalam menghadapi situasi pemicu stres yang sebagian besar berada di luar kendali mereka. Teknik self-instructional ini menekankan pada upaya mengajari klien untuk mengendalikan emosi negatif dari pada semata-mata menghilangkannya. Kemudian melalui modeling dan gladi perilaku, klien mempelajari instruksi diri yang tepat untuk melawan pernyataan diri yang negatif ketika menghadapi situasi negatif atau tidak menyenangkan dalam hidupnya.

Sejumlah besar penelitian mengindikasikan bahwa strategi self-instruction training efektif untuk beberapa permasalahan yang relatif spesifik seperti pengendalian impulsivitas, pengembangan asertifitas, membangun motivasi, dan peningkatan keterampilan mengelola waktu (Meichenbaun, 1986). Selain itu Hatzigeorgiadis et al (2010) menemukan bahwa pemberian motivasi melalui verbalisasi diri dapat meningkatkan kepercayaan diri dan mengurangi kecemasan pemain tenis pada saat akan mengikuti kejuaraan tenis. Penelitian lain yang dilakukan Kanfer (Safaria, 2004, hlm. 95) menggunakan prosedur self-instruction untuk mengatasi anak yang takut terhadap malam hari dan mempunyai dampak yang besar dalam menurunkan tingkat ketakutan anak.

Self-instruction training menjadi salah satu alternatif yang dipilih peneliti untuk meningkatkan resiliensi siswa hal ini didasarkan atas pertimbangan literatur dan beberapa penelitian yang sebelumnya dibahas pada bagian latarbelakang yang menunjukan keefektifan self-instruction training dalam mengatasi beberapa masalah psikologis. Selain itu, self-instruction training dipandang praktis dan mudah dilakukan oleh para remaja tanpa didampingi instruktur setelah mengikuti pelatihan terlebih dahulu. Perlu dilakukan kajian ilmiah mengenai keefektifan dan formulasi self-instruction training seperti apa yang mampu meningkatkan resiliensi remaja ini. Dengan demikian penelitian perlu difokuskan pada permasalahan utama yakni perlu dirumuskannya self-instruction training yang teruji efektif untuk meningkatkan resiliensi remaja.

\section{METODE PENELITIAN}

Pendekatan penelitian yang digunakan adalah Pendekatan kuantitatif. Pendekatan kuantitatif sebagai pendekatan ilmiah didisain untuk menjawab pertanyaan penelitian atau hipotesis secara spesifik dengan penggunaan statistik dianggap relevan oleh peneliti sebagai pendekatan yang digunakan untuk mengetahui efektivitas teknik self-instruction training untuk meningkatkan resiliensi siswa. Menurut Cresswell (2008, hlm. 46) pendekatan kuantitatif merupakan jenis penelitian pendidikan dimana para peneliti memutuskan apa yang harus diteliti, memiliki pertanyaan yang lebih fokus, menganalisis data menggunakan analisis statistik, dan melakukan penyelidikan tersebut dengan cara yang objektif.

Metode yang digunakan dalam penelitian ini adalah Quasi Experimental. Quasi experimental mempunyai kelompok kelompok kontrol, tetapi tidak dapat berfungsi sepenuhnya untuk mengontrol variabel-variabel luar yang mempengaruhi pelaksanaan 
eksperimen (Sugiyono, 2012, hlm. 114). Desain eksperimen yang digunakan adalah Nonequivalent Pretest-Posttest Control Group Design, yaitu desain penelitian yang dilaksanakan terhadap dua kelompok, yakni kelompok eksperimen dan kelompok kontrol.

Dalam desain Nonequivalent Pretest-Posttest Control Group, kelompok eksperimen maupun kelompok kontrol tidak dipilih secara random. Kelompok kontrol merupakan kelompok pembanding dan tidak diberikan perlakuan, sedangkan kelompok eksperimen diberikan perlakuan berupa teknik self-instruction training. Kedua kelompok dikenakan pengukuran sebanyak dua kali sebelum dan sesudah diberikan perlakuan (Sugiyono, 2012, hlm. 116). Data pretest-posttest diambil melalui instumen untuk mengungkap tingkat resiliensi siswa. Skema model penelitian quasi eksperimental dengan desain Nonequivalent Pretest-Posttest Control Group, sebagai berikut.

\begin{tabular}{|lll|}
\hline $\mathbf{O}_{1}$ & $\mathbf{x}$ & $\mathbf{O}_{2}$ \\
\hline $\mathbf{O}_{3}$ & & $\mathbf{O}_{4}$ \\
\hline
\end{tabular}

(Campbell \& Stanley, 1963, hlm. 47)

Lokasi penelitian ini dilaksanakan di SMAN 1 Mangunjaya yang berlokasi di Kecamatan Mangunjaya Kabupaten Pangandaran. Dalam penelitian ini populasi penelitiannya adalah siswa kelas X dan XI SMAN 1 Mangunjaya yang secara administratif terdaftar dan aktif dalam pembelajaran yang berjumlah 504 orang siswa. Pengambilan sampel dalam penelitian ini menggunakan teknik purposive sampling (sampel bertujuan).

Sampel dalam penelitian ini adalah seluruh siswa kelas $\mathrm{X}$ dan XI SMAN 1 Mangunjaya. Hal ini mengacu pada pendapat Schoon (2006, hlm. 9) bahwa setiap individu memiliki kapasitas resiliensi yang berbeda antara satu dengan yang lainnya, semakin tinggi kapasitas resiliensi individu maka semakin baik ketahanan dalam menghadapi masalah sehingga terhindar dari perilaku-perilaku yang merugikan bagi kehidupannya. Dengan demikian secara umum siswa kelas X dan XI yang telah teridentifikasi tingkat resiliensinya berdasarkan pretest instrumen resiliensi remaja menjadi sampel penelitian. Sehingga peneliti mengambil kelas X sebagai kelas eksperimen yang akan diberikan perlakuan berupa teknik self-instruction training dan kelas XI sebagai kelas kontrol yang berperan sebagai kelompok pembanding yang tidak diberikan perlakuan.

Analisis data terkait efektivitas self-instruction training untuk meningkatkan resiliensi siswa, terlebih dahulu dilakukan uji normalitas dengan menggunakan rumus uji z Kolmogorov-Smirnov terhadap skor pre test, skor post test dan gain score kelompok eksperimen dan kontrol. Kemudian untuk mengetahui keefektifan self-instruction training untuk meningkatkan resiliensi siswa dilakukan analisis terhadap skor pre test dan skor post test dengan menggunakan teknik statistik berupa uji perbedaan dua rerata ( $t$-test). Adapun teknik analisis data dilakukan dengan menggunakan bantuan perangkat lunak Statistical Product and Service Solutions (SPSS) versi 19.0. 


\section{HASIL DAN PEMBAHASAN}

\section{Hasil Penelitian}

Keseluruhan populasi penelitian (504 orang) ditetapkan sebagai sampel penelitian. Data mengenai profil resiliensi siswa diperoleh dari hasil penyebaran instrumen skala resiliensi siswa terhadap sampel penelitian. Dari data yang terkumpul, diperoleh profil resiliensi siswa dan gambaran aspek resiliensi siswa. Hasil pengumpulan data tersebut kemudian diolah dan dijadikan bahan pertimbangan untuk mengembangkan program selfinstruction training untuk meningkatkan resiliensi siswa.

Data penelitian menunjukkan bahwa profil resiliensi siswa yakni sebesar 7,34\% dari keseluruhan siswa yang menjadi sampel penelitian memiliki resiliensi pada tingkatan tinggi atau berada pada kategori resilien, 77,78\% memiliki resiliensi pada tingkatan sedang atau berada pada kategori cukup resilien, dan 14,88\% memiliki resiliensi pada tingkatan rendah atau berada pada kategori kurang resilien. Secara lebih rinci profil resiliensi siswa disajikan pada tabel 1 .

Tabel 1. Profil umum resiliensi siswa SMAN 1 Mangunjaya

\begin{tabular}{|l|l|c|c|}
\hline \multicolumn{1}{|c|}{ Tingkatan } & \multicolumn{1}{c|}{ Kategori } & Frekuensi & Persentase \\
\hline Tinggi & Resilien & 37 & 7,34 \\
\hline Sedang & Cukup Resilien & 392 & 77,78 \\
\hline Rendah & Kurang Resilien & 75 & 14,88 \\
\hline
\end{tabular}

Efektivitas self-instruction training dapat terlihat dari perubahan data antara perbandingan data pretes dan data postes kelas eksperimen sebagai kelas yang diberi perlakuan dan kelas kontrol yang tidak diberikan perlakuan. Penyajian pada bagian ini merupakan jawaban atas pertanyaan penelitian yang ketiga yakni perubahan data resiliensi antara pretes dan postes. Berikut ini disajikan data resiliensi siswa hasil perbandingan pretes dan postes kelas kontrol dan eksperimen.

\section{Perubahan Data Resiliensi Siswa Kelas Kontrol}

Terdapat perubahan data resiliensi siswa pada kelas kontrol yang tidak diberikan perlakuan self-instruction training. Perubahan data resiliensi siswa kelas kontrol antara pretes dan postes tersaji pada tabel 2 .

Tabel 2. Perbandingan Data Resiliensi Pretes dan Postes Siswa Kelas Kontrol

\begin{tabular}{|c|c|c|c|c|}
\hline \multirow{2}{*}{ Tingkatan } & \multicolumn{2}{|c|}{ Pretes } & \multicolumn{2}{c|}{ Postes } \\
\cline { 2 - 5 } & Frekuensi & Persentase & Frekuensi & Persentase \\
\hline Tinggi & 37 & 14,74 & 31 & 12,35 \\
\hline Sedang & 178 & 70,92 & 186 & 74,10 \\
\hline Rendah & 36 & 14,34 & 34 & 13,54 \\
\hline
\end{tabular}


Dari data tersebut dapat disimpulkan terdapat perubahan data resiliensi kelas kontrol pretes dan postes pada kategori tinggi mengalami penurunan persentasi, sedangkan pada kategori sedang mengalami kenaikan persentasi, dan pada kategorti rendah kembali mengalami penurunan. Selain dikaji perubahan berdasarkan kategori tingkat resiliensi, dikaji pula tingkat ketercapaian resiliensi yang dimiliki siswa SMAN 1 Mangunjaya. Adapun data perbandingan tingkat ketercapaian resiliensi siswa tersaji pada tabel 3 .

\section{Tabel 3. Perbandingan Data Tingkat Ketercapaian Resiliensi Pretes dan Postes} Siswa Kelas Kontrol

\begin{tabular}{|c|c|c|}
\hline Ketercapaian & Pretes Kelas Kontrol & Pretes Kelas Kontrol \\
\hline Tingkat Ketercapaian (\%) & 39,79 & 37,09 \\
\hline
\end{tabular}

\section{Perubahan Data Resiliensi Siswa Kelas Eksperimen}

Perubahan data resiliensi siswa pada kelas eksperimen setelah diberikan perlakuan self-instruction training. Perubahan data resiliensi siswa kelas eksperimen antara pretes dan postes tersaji pada tabel 4.

Tabel 4. Perbandingan Data Resiliensi Pretes dan Postes Siswa Kelas Eksperimen

\begin{tabular}{|c|c|c|c|c|}
\hline \multirow{2}{*}{ Tingkatan } & \multicolumn{2}{|c|}{ Pretes } & \multicolumn{2}{c|}{ Postes } \\
\cline { 2 - 5 } & Frekuensi & Persentase & Frekuensi & Persentase \\
\hline Tinggi & 24 & 9,48 & 31 & 12,25 \\
\hline Sedang & 211 & 83,39 & 217 & 85,77 \\
\hline Rendah & 18 & 7,11 & 5 & 1,97 \\
\hline
\end{tabular}

Dari data tersebut dapat disimpulkan terdapat perubahan data resiliensi kelas eksperimen pretes dan postes pada kategori tinggi mengalami kenaikan persentasi, begitu pula pada kategori sedang mengalami kenaikan persentasi, sedangkan pada kategorti rendah mengalami penurunan. Selain dikaji perubahan berdasarkan kategori tingkat resiliensi, dikaji pula tingkat ketercapaian resiliensi kelas eksperimen yang dimiliki siswa SMAN 1 Mangunjaya. Adapun data perbandingan tingkat ketercapaian resiliensi siswa tersaji pada tabel 5.

Tabel 5. Perbandingan Data Tingkat Ketercapaian Resiliensi Pretes dan Postes Siswa Kelas Eksperimen

\begin{tabular}{|c|c|c|}
\hline Ketercapaian & $\begin{array}{c}\text { Pretes Kelas } \\
\text { Eksperimen }\end{array}$ & $\begin{array}{c}\text { Pretes Kelas } \\
\text { Eksperimen }\end{array}$ \\
\hline Tingkat Ketercapaian (\%) & 34,35 & 38,73 \\
\hline
\end{tabular}




\section{Hasil Uji Efektivitas Menggunakan Prosedur Statistik}

Uji efektivitas self-instruction training untuk meningkatkan resiliensi siswa dimulai dengan uji normalitas dan homogenitas. Jika data berdistribusi normal maka selanjutnya akan menguji homogenitas variansinya, dan uji $\mathrm{T}$, namun jika data tidak berdistribusi normal maka akan digunakan uji Mann Whitney.

\section{a. Uji Normalitas}

Uji normalitas digunakan untuk mengetahui apakah data yang diperoleh berdistribusi normal atau tidak. Pengujian normalitas data menggunakan bantuan software SPSS 16.0 for windows dengan uji statistik Kolmogorov-Smirnov atau ShapiroWilk menggunakan taraf signifikansi 5\%. Hipotesis yang digunakan pada uji normalitas adalah sebagai berikut.

$H_{0}$ : Data pretest kelas kontrol dan kelas eksperimen berdistribusi normal

$H_{1}$ : Data pretest kelas kontrol dan kelas eksperimen berdistribusi tidak normal

Kriteria pengujiannya adalah sebagai berikut.

Jika Sig. $\geq 0,05$ maka $\mathrm{H}_{0}$ diterima.

Jika Sig. $<0,05$ maka $\mathrm{H}_{0}$ ditolak.

Jika kedua data berdistribusi normal maka dilanjutkan dengan uji homogenitas varians. Jika salah satu atau kedua data yang dianalisis berdistribusi tidak normal maka tidak dilakukan uji homogenitas varians melainkan dilakukan uji statistik nonparametrik yaitu uji Mann-Whitney. Beikut hasil uji normalitas tersaji pada tabel 6.

Tabel 6. Tests of Normality

\begin{tabular}{|cc|c|c|c|c|c|c|}
\hline \multirow{2}{*}{ Data Pretes } & \multicolumn{3}{|c|}{ Kolmogorov-Smirnov(a) } & \multicolumn{3}{c|}{ Shapiro-Wilk } \\
\cline { 2 - 8 } & Statistic & df & Sig. & Statistic & df & Sig. \\
\hline VAR00001 & eksperimen &, 063 & 253 &, 016 &, 964 & 253 &, 000 \\
& kontrol &, 115 & 251 &, 000 &, 949 & 251 &, 000 \\
\hline
\end{tabular}

a Lilliefors Significance Correction

Dari tabel uji normalitas di atas diperoleh nilai signifikansi skor pretest dengan menggunakan uji Kolmogorov-Smirnov untuk kelas eksperimen sebesar 0.016 dan kelas kontrol sebesar sebesar 0,000 , pada taraf signifikansi $\alpha=0.05$. Sedangkan jika diuji dengan uji Shapiro-Wilk maka didapat nilai signifikansi kelas eksperimen sebesar 0,000 dan kelas kontrol sebesar 0,000 . Oleh karena nilai signifikansi untuk masing-masing kelas kontrol dan eksperimen lebih kecil dari $\alpha=0.05$, maka $\mathrm{H} 1$ yang diterima dan $\mathrm{H} 0$ ditolak, dengan kata lain data pretest kelas kontrol dan kelas eksperimen berdistribusi tidak normal, kecuali kelas eksperimen sebesar 0.016 lebih besar dari $\alpha=0.05$ yang berarti data tersebut berdistribusi normal. 


\section{b. Uji Homogenitas}

Dalam penghitungan uji homogenitas bisa menggunakan bantuan software SPSS 16 for windows dengan menggunakan taraf signifikansi $5 \%$. Hipotesis yang digunakan pada uji homogenitas adalah sebagai berikut.

$H_{0}$ : Data pretest kelas kontrol dan kelas eksperimen homogen

$H_{1}$ : Data pretest kelas kontrol dan kelas eksperimen tidak homogen

Kriteria pengujiannya adalah sebagai berikut.

Jika Sig. $\geq 0,05$ maka $\mathrm{H}_{0}$ diterima.

Jika Sig. $<0,05$ maka $\mathrm{H}_{0}$ ditolak.

Hasil uji homogenitas tersaji pada tabel 7.

Tabel 7. Uji homogenitas

\begin{tabular}{|c|c|c|c|}
\hline $\begin{array}{l}\text { Levene } \\
\text { Statistic }\end{array}$ & df1 & df2 & Sig. \\
\hline 15.089 & 1 & 504 & .000 \\
\hline
\end{tabular}

Dari tabel uji homogenitas data pretes di atas diperoleh hasil dari uji Levene Statistic skor pretest untuk kelas kontrol dan eksperimen sebesar 0,000, pada taraf signifikansi $\alpha=0.05$. Maka berdasarkan hiipotesis yang digunakan untuk uji homogenitas ini $\mathrm{H} 1$ yang diterima dan $\mathrm{H} 0$ ditolak, dengan kata lain data pretest kelas kontrol dan kelas eksperimen tidak homogen. Dari hasil di atas dapat terlihat bahwa data skor pretes kelompok ekperimen dan kelompok kontrol berasal dari populasi yang tidak berdistribusi normal dan tidak homogen, maka uji hipotesis yang digunakan adalah uji Mann-Whitney.

\section{c. Uji Hipotesis Penelitian}

Dalam menghitung uji hipotesis penelitian dengan menggunakan uji MannWhitney, sebelumnya dipaparkan hipotesis terlebih dahulu. Hipotesis penelitian dalam penelitian self-instruction training untuk meningkatkan resiliensi siswa yang akan diuji yakni sebagai berikut:

$$
\begin{aligned}
& \text { Ho }: \mu_{1}=\mu_{2} \\
& \text { H1 }: \mu_{1}>\mu_{2}
\end{aligned}
$$

Keterangan:

$\mu_{1} \quad=$ rata-rata peningkatan resiliensi kelompok eksperimen.

$\mu_{2} \quad=$ rata-rata peningkatan resiliensi kelompok kontrol.

Uji Mann-Whitney digunakan untuk mengetahui ada atau tidaknya perbedaan yang signifikan (meyakinkan) dari rerata gain pre tes dan pos tes resiliensi siswa kelas eksperimen dan kelas kontrol. Uji Mann-Whitney dihitung dengan menggunakan program SPSS 16. Hasil perhitungan disajikan pada tabel 8. 


\section{Tabel 8. Hasil Uji Mann-Whitney Skor Pretes dan Postes Kelas Eksperimen dan Kelas Kontrol}

\begin{tabular}{|l|r|}
\hline & \multicolumn{1}{|c|}{ skor } \\
\hline Mann-Whitney U & 22603,000 \\
Wilcoxon W & 54734,000 \\
Z & $-5,718$ \\
Asymp. Sig. (2-tailed) &, 000 \\
\hline
\end{tabular}

Dari Tabel 4.11 di atas terlihat bahwa nilai signifikansi (sig.) sebesar 0.000 lebih kecil dari $\alpha=0.05$, sehingga kesimpulan statistik yang diambil adalah H1 diterima, artinya self-instruction training efektif untuk meningkatkan resiliensi siswa.

\section{Pembahasan}

\section{Profil Resiliensi Siswa}

Data hasil penelitian mengindikasikan profil resiliensi siswa yakni bahwa mayoritas siswa memiliki kecenderungan resiliensi pada tingkat sedang atau termasuk dalam kategori cukup resilien. Hal ini menunjukkan bahwa tingkat kecenderungan resiliensi siswa sampel penelitian belum mencapai tahap optimal dalam arti masih perlu ditingkatkan, ditambah lagi fakta bahwa jumlah siswa sampel penelitian yang memiliki kecenderungan resiliensi pada tingkat rendah atau termasuk dalam kategori kurang resilien dapat dikatakan masih cukup banyak.

Beberapa studi sebelumnya yang dilakukan oleh berbagai pakar dan praktisi, terutama di bidang kesehatan mental, mengindikasikan hasil yang seiring sejalan terkait profil resiliensi siswa dan kebutuhan akan upaya peningkatan resiliensi dalam diri siswa. Penelitian terbaru dilakukan oleh Castro (2011) terhadap 937 orang siswa di Texas Selatan yang mengikuti program berbasis kecerdasan emosional, keseluruhan siswa termasuk dalam kategori siswa beresiko dan $34 \%$ diantaranya berasal dari keluarga dengan status ekonomi rendah. Hasil pre test menunjukkan bahwa 25,9\% siswa menunjukkan resiliensi pada kategori under-average, 57\% diantaranya berada pada kategori average, dan sisanya sebanyak $18 \%$ berada pada kategori above-average.

Studi lain yang turut mendukung hasil penelitian adalah penelitian yang dilakukan oleh Parinyaphol dan Chongruksa (2008) dari universitas Prince Sonkla Thailand terhadap 7669 orang mahasiswa tingkat pertama di universitas Prince Sonkla Thailand. Penelitian dilakukan dengan mengadministrasikan kuesioner yang konstruknya dikembangkan dari aspek resiliensi yang dikemukakan oleh Grotberg yakni I AM, I $H A V E$ dan I CAN. Data hasil penelitian mengindikasikan skor rata-rata resiliensi sebanyak 76,89 menggambarkan bahwa populasi penelitian memiliki resiliensi pada tingkatan moderat atau sedang $(M=76.896, S D=8.55)$. Hasil penelitian juga dijabarkan dalam bentuk persentase subjek penelitian yang termasuk dalam masing-masing kategori 
resiliensi yakni $35,72 \%$ subjek memiliki resiliensi tinggi, 74,84\% memiliki resiliensi sedang dan 15,30\% memiliki resiliensi rendah.

Thomsen (2002; dalam Castro, Johnson \& Smith, 2011) mengemukakan, bahwa semua individu telah memiliki modal yang cukup untuk mengembangkan resiliensi, modal tersebut berupa kapasitas adaptasi yang sifatnya alamiah dan instingtif oleh karena itu individu hanya tinggal membuka lebar kapasitas tersebut untuk meningkatkan kemampuan merespon secara positif dampak negatif dari pengalaman adversitas. Hal tersebut diprediksi menjadi salah satu alasan mengapa dalam banyak studi lainnya tingkatan resiliensi yang dominan ditunjukkan oleh populasi penelitian atau subjek penelitian adalah resiliensi dalam tingkatan sedang, atau rata-rata (average), atau moderat, yakni karena individu memiliki suatu kapasitas alamiah dalam diri mereka untuk merespon terhadap berbagai pengalaman yang sifatnya menyakitkan, menekan, dan mengancam.

Berbagai kecenderungan yang memperkokoh hasil penelitian terkait tingkatan resiliensi siswa yang mayoritas berada pada kategori sedang atau moderat tidak menjadikan upaya untuk meningkatkan resiliensi siswa berkurang urgensinya. Berbagai fakta menegaskan bahwa pengembangan resiliensi sangat diperlukan oleh siswa sebagai kompetensi menghadapi transisi menuju masa dewasa yang sarat tantangan dan tekanan, serta untuk memperoleh status kesehatan mental yang sehat dan terpelihara sepanjang masa kehidupan selanjutnya (Kaplan, 1999; dalam Goldstein \& Brown, 2005, hlm. 29).

Sampson dan Laub (1993; dalam Goldstein \& Brown, 2005, hlm. 29) melakukan studi longitudinal yang mengungkap bahwa perilaku bermasalah yang muncul pada anak dan siswa seperti kegagalan akademik, delikuensi, masalah kesehatan mental, pola perilaku mall adaptif dan menyimpang, menjadikan status kesehatan mental individu menjadi tidak stabil pada tahapan perkembangan selanjutnya. Pertimbangan lain mengenai kemungkinan bahwa dampak dari adversitas tidak muncul secara segera akan tetapi dapat muncul sekian lama kemudian di masa depan, dibuktikan dengan adversitas awal yang terjadi pada anak atau siswa yang mengalami pengabaian atau kekerasan oleh orang tua nya dapat berdampak pada kemampuan anak atau siswa tersebut untuk membangun keluarga yang fungsional dimasa dewasa (Dilillo, 2001 dalam Anesty, 2012, hlm. 163). Anak atau siswa yang mengalami adversitas khususnya yang bersifat traumatik dan bertahan lama, cenderung rentan terhadap simptom distress yang dapat mereka alami dimasa depan, karena alasan tersebut maka kemampuan resiliensi yang sifatnya berkelanjutan sangat tepat dipertimbangkan dalam menghadapi kerentanan yang berlanjut pula serta untuk tanggap terhadap berbagai dinamika perubahan keberfungsian anak dan siswa sepanjang waktu (Kaplan, 2002 dalam Anesty, 2012, hlm.165).

\section{Efektivitas Self-Instruction Training untuk Meningkatkan Resiliensi Siswa}

Tujuan uji efektivitas intervensi adalah untuk memperoleh gambaran mengenai sejauh mana intervensi self-instruction training efektif untuk meningkatkan resiliensi siswa. Hasil uji efektivitas melalui perubahan dan perbandingan data pretes dan postes 
kelas kontrol dan eksperimen menunjukkan bahwa intervensi telah efektif meningkatkan resiliensi siswa. Disamping itu, dari data hasil uji efektivitas menggunakan analisis statistik, yakni uji mann whitney, diperoleh gambaran bahwa terdapat perbedaan yang signifikan antara hasil pre test dan hasil post test kelas eksperimen dan kontrol. Data tersebut, pada intinya menunjukkan bahwa self-instruction training efektif untuk meningkatkan resiliensi siswa.

Upaya peningkatan resiliensi dalam bentuk program intervensi juga tidak terlepas dari sudut pandang pedagogis terhadap resiliensi yakni resiliensi diyakini sebagai kemampuan anak untuk bangkit dari situasi adversitas dengan menggunakan kapasitas merespon dan bertahan serta mengembangkan atau memelihara kehidupan yang sehat dalam menghadapi stressor (Garmezy, 1983; McClelland 2000; Minnard, 2002; NMHWG \& NCCHC, 2000; dan Rutter \& Rutter 1992; dalam Russo \& Boman, 2007). Dalam upaya mengurangi efek dari situasi adversitas dan membangun resiliensi, sejumlah pakar pedagogis mengidentifikasi sejumlah faktor protektif baik yang dibangun menggunakan aset internal (faktor biologis dan psikologis) maupun aset eksternal (keluarga, teman sepergaulan, komunitas dan institusi sosial).

Praktik pendidikan di sekolah menjadi salah satu aset eksternal yang penting dalam mendukung faktor protektif yang memungkinkan anak untuk mengurangi kerentanan anak terhadap stressor dan menjadikan anak lebih resilien (Garmezy, 1985; Mandleco \& Craig, 2000; Rutter, 1987; dalam Russo \& Boman, 2007). Dengan demikian, proses pendidikan menjadi landasan penting dalam pengembangan berbagai program intervensi yang bertujuan untuk meningkatkan resiliensi individu khususnya anak dan siswa.

Desain intervensi eksperimental dapat memberikan pengujian hipotesis yang powerfull mengenai bagaimana proses resiliensi terjadi, intervensi seperti apa yang diasosiasikan dengan proses tersebut, serta perubahan sub sekuen yang dihubungkan dengan perubahan dalam proses resiliensi terkait perilaku target individu atau sistem (Masten, 2001). Kraemer dkk (2002, dalam Anesty, 2012) menspesifikasikan dengan baik bagaimana desain intervensi eksperimental dapat menguji efek mediasi dan moderator, dengan penyajian intervensi yang sesuai dengan proses mediasi atau moderator yang dihipotesiskan. Eksperimen juga dapat mengidentifikasi siapa yang paling diuntungkan oleh treatment atau perlakuan, aspek mana yang sangat termediasi oleh perubahan dan untuk menguji efek mediasi dan moderator tambahan dari intervensi.

Intervensi yang berorientasi pada pendekatan dan teori psikologi juga memegang peran penting dalam upaya peningkatan resiliensi individu khususnya siswa. Beberapa program beorientasi psikoterapi yang telah dilaksanakan dan terbukti efektif dalam meningkatkan resiliensi individu yang menjadi subjek intervensi, dirangkum dalam studi meta-analisis yang dilakukan oleh Hooper (2008) yang mengemukakan bahwa terapi kognitif behavioral menempati tempat pertama intervensi yang teruji efektif dalam meningkatkan resiliensi individu khususnya mereka yang menjadi korban bencana alam dan pengalaman traumatik lain. 
Bush (dalam Ilfiandra, 2008: 2) menyatakan bahwa ' ...cognitive-behavior therapy (CBT) has become the preferred treatment for most emotional and behavior problems'. Terapi kognitif-perilaku merupakan pendekatan yang banyak digunakan dalam menangani masalah kognitif dan perilaku. Pendekatan kognitif-perilaku untuk meningkatkan resiliensi siswa dalam penelitian ini adalah dengan menggunakan pendekatan Pelatihan Instruksi Diri (self-instruction training). Teknik self-instructional ini menekankan pada upaya mengajari siswa untuk mengendalikan emosi negatif dari pada semata-mata menghilangkannya. Kemudian melalui modeling dan gladi perilaku, siswa mempelajari instruksi diri yang tepat untuk melawan pernyataan diri yang negatif ketika menghadapi situasi negatif seperti adversitas.

Meskipun terdapat beragam teori dan hasil penelitian yang membahas bagaimana resiliensi siswa terbentuk dan berkembang, bagaimana resiliensi siswa tersebut terpelihara dan bagaimana upaya peningkatan terhadap resiliensi siswa, namun cela utama dari berbagai upaya dan metode yang bertujuan untuk mengeliminasi resiliensi siswa dalam kelas belum sepenuhnya diimplementasikan dalam ruang kelas yang sebenarnya, melainkan hanya baru teruji efektif ketika diimplementasikan dalam suatu desain eksperimental yang disengaja atau sarat manipulasi terapeutik (Stober, 2004, dalam Azzi, 2012).

Keberhasilan teknik self-instruction dalam mereduksi resiliensi siswa pada dasarnya tidak terlepas dari berbagai kelebihan yang dimiliki oleh teknik self-instruction itu sendiri. Sleight (1997) mengemukakan kelemahan dan kelebihan teknik selfinstruction dalam konteks psikoterapi Beberapa kelebihan dari teknik self-instruction antara lain :

a. Efisien dalam hal waktu dan biaya. Sekali rangkaian intervensi self-instruction dikembangkan, hanya sedikit waktu yang dibutuhkan untuk memeliharanya. Terapis dapat menggunakan waktunya untuk melatih dan mengawasi klien ketika melakukan self-instruction namun tetap memiliki waktu untuk melakukan proyek pelatihan lain.

b. Teknik self-instruction dapat mencakup rentan yang luas dalam hal permasalahan klien.

c. Teknik self-instruction memungkinkan klien untuk memegang kendali dalam hal pemberian instruksi. Jenis kendali dapat beragam, mulai dari kendali sederhana terhadap langkah- langkah instruksi, kendali untuk menentukan tujuan terapi sampai pada kendali untuk menentukan materi instruksi yang mereka butuhkan.

Selain kelebihan kelebihan yang telah dikemukakan diatas terdapat pula beberapa kelemahan dari teknik self-instruction diantaranya:

a. Kurangnya kesempatan bagi terapis untuk memfasilitasi pembelajaran melalui pembagian gagasan dalam kelompok atau antara satu klien dengan klien lain.

b. Teknik self-instruction mensyaratkan kemampuan yang lebih dalam diri klien untuk memberi instruksi kepada dirinya sendiri bukan hanya mengandalkan 
instruksi dari terapis, oleh karena itu klien harus memotivasi diri mereka sendiri untuk memulai dan melanjutkan instruksi. Hal tersebut merupakan tugas yang cukup berat bagi terapis maupun klien untuk mempertahankan motivasi sampai sesi intervensi berakhir.

c. Instruksi yang diberikan dalam intervensi menggunakan teknik self-instruction biasanya bersifat statis tidak beradaptasi dengan kemajuan yang dicapai klien. Berdasarkan penelitian terapis yang intelijen dapat menyesuaikan instruksi yang diberikan dengan kebutuhan klien pada tiap sesinya, akan tetapi hal tersebut tidak mudah dilakukan.

\section{SIMPULAN}

Hasil penelitian mengindikasikan profil resiliensi remaja, mayoritas remaja berada pada kategori cukup resilien. Intervensi terhadap kedelapan aspek tersebut dilakukan dengan menggunakan self-instruction training yakni dengan memanfaatkan verbalisasi diri untuk mengontrol mindset kedelapan aspek resiliensi tersebut agar lebih adaptif bagi diri siswa. Penggunaan teknik tersebut didasarkan atas kajian pustaka dan penelitian terdahulu yang menunjukkan keberhasilan self-instruction training dalam melatihkan keterampilan pemecahan masalah dan keterampilan sebagai strategi coping. Intervensi self-instruction training untuk meningkatkan resiliensi siswa teruji efektif dalam mengembangkan seluruh aspek resiliensi, terutama pada aspek efikasi diri, penilaian realistis terhadap lingkungan, problem solving, dan planning \& goal setting.

\section{DAFTAR PUSTAKA}

Anesty, E. (2012). Konseling Rasional Emotif Behavioral Untuk meningkatkan Resiliensi Remaja. Tesis pada Sekolah Pascasarjana UPI Bandung: Tidak diterbitkan.

Azzi, P. A. (2012). Efektivitas Teknik Self-Instruction untuk Mereduksi Kecemasan Menghadapi Ujian. Bandung: Skripsi Jurusan PPB-FIP UPI. (Tidak Diterbitkan).

Barnard, P. M. I. \& Nagy, J. (1999). Children, Bereavement and Trauma : Nurturing Resilience. London : Jessica Kingsley Publisher.

Campbell, D. T. \& Stanley, J. C. (1963). Experimental and Quasi-Experimental Designs for Research. Boston: Houghton Mifflin Company.

Castro, V., Johnson, M. B. \& Smith, R. (2011). Self-Reported Resilient Behaviors of Seventh and Eighth Grade Students Enrolled in an Emotional Intelligence Based Program. (Lecture Paper). Universitas of Texas Pan American.

Creswell, J. W. (2008). Educational Research (Fourth Edition). Boston: Pearson Education.

Desmita. (2009). Psikologi Perkembangan. Bandung. Remaja Rosdakarya. 
Goldstein, S., \& Brooks, R. B. (2005). Handbook of Resilience in Children. New York, USA: Springer Science and Business Media, Inc.

Hatzigeorgiadis, A. Zourbanos, N. Mpoumpaki, S. \& Theodorakis, Y. (2010). Mechanisms underlying the self-talk-performance relationship: The effects of motivational selftalk on self-confidence and anxiety. Psychology of Sport and Exercise, 2009. 10: 186192.

Hooper, L. M. (2008). Individual and Family Resilience: Definitions, Research, and Frameworks (Relevant for All Counselors). The Alabama Counseling Association Journal, Volume 35, no 1. 19-26.

Hurlock, E. (2003). Psikologi Perkembangan, Suatu Pendekatan Sepanjang Rentang kehidupan. Jakarta: Erlangga.

Ilfiandra. (2008). Model Konseling Kelompok Berbasis Pendekatan Kognitif Perilaku Untuk Mengurangi Gejala Prokrastinasi Akademik (Disertasi). Bandung: SPS UPI.

Isaacson, B. (2002). Characteristics and Enhancement of Resiliency in Young People : A Research Paper Tersedia :http://www.uwstout.ede/lib/thesis/2002/2002isaacsonb.pdf.(3 Desember 2013)

Linley, P. A, \& Joseph, S. (2004). Positive Psychology In Prctice. New Jersey: John Wiley \& Sons, Inc.

Liquanti, R. (1992). Using Community-wide Collaboration to Foster Resiliency in Kids: A Conceptual Framework Western Regional Center For Drugs-Free School and Communities, Far West Laboratory fo Educational Research and Development. San Fransisco. (Online). Tersedia : http://www.ncrel.org/sdrs/cityschool/citu11bhtm (diakses : 24-10-2010).

Masten, A. S., Best, K. M., \& Garmezy, N. (2001). Resilience and development: Contributions from the study of children who overcome adversity. Journal of Development and Psychopathology, 2, 425-444.

Meichenbaum, D. \& Goodman, J. (1971). Training Impulsive Children to Talk to Themselves: A Means of Developing Self-Control. Journal of Abnormal Psychology, 77, hlm. 115-126.

Meichenbaum, D. (1971). Cognitive-Behavior Modification: An Integrative Approach (second printing). New York: Plenum Press.

Parinyaphol, P., \& Chongruksa, D. (2008). Resilience of Higher Educational Students : The Human Spirit Among Thai and Muslim Students. Journal in Department of Psychology and Guidance, Prince of Songkla University (7:08). 
Russo, R., \& Boman, P. (2007). Primary School Teachers' Ability to Recognise Resilience in their Students. The Australian Educational Researcher Vol. 34 (1), April, 17-32.

Safaria, T. (2004). Terapi Kognitif Perilaku Untuk Anak. Yogyakarta : Graha Ilmu.

Santrock, J. W. (1996). Life-Span Develompment : Perkembangan Masa Hidup. Jakarta : Erlangga.

Schoon, I. (2006). Risk and Resilience, Adaptations in Changing Times. New York : Cambridge University Press.

Slavin, E. R. (2011). Psikologi Pendidikan. Teori dan Praktik. Jakarta: Indeks.

Sugiyono. (2012). Metode Penelitian Pendidikan. Bandung : CV. Alfabeta.

Tugade, M. M. \& Fredrickson, B. L. (2004). Resilient individuals use positive emotions to bounce back from negative emotional experiences. Journal of Personality and Social Psychology, 86, 320 - 333. 